\title{
ANALISIS PELAKSANAAN PENGEMBANGAN SUMBER DAYA MANUSIA PADA KANTOR DINAS KEPARIWISATAAN KABUPATEN KEPULAUAN SELAYAR
}

\author{
Analysis of The Implementation of Human Resources Development in Office of Tourism Department \\ Kepulauan Selayar Regency
}

\author{
Arini Handayani ${ }^{1}$, Husain Hamka ${ }^{2}$, Syamsuddin Maldun ${ }^{2}$ \\ ${ }^{1}$ Dinas Kebudayaan dan Pariwisata, Kabupaten Kepulauan Selayar \\ ${ }^{2}$ Program Studi Administrasi Negara, Program Pascasarjana Universitas Bosowa \\ Email: arinihandayani9105@gmail.com
}

Diterima: 17 Maret 2020

Dipublikasikan: 05 Juni 2020

\begin{abstract}
ABSTRAK
Penelitian ini bertujuan untuk menganalisis pengaruh pendidikan dan latihan terhadap pengembangan SDM pada Dinas Kepariwisataan Kabupaten Kepulauan Selayar dan motivasi kerja terhadap pengembangan SDM pada Dinas Kepariwisataan Kabupaten Kepulauan Selayar. Jenis penelitian ini adalah kuantitatif deskriptif, populasi dan sampel dalam penelitian berjumlah 50 pegawai. Penentuan sampel menggunakan teori slavin, penelitian ini dianalisis melalui Analisis regresi Linear berganda dengan bantuan software SPSS 23. Hasil penelitian menunjukkan bahwa pendidikan dan latihan berpengaruh positif dan signifikan pengembangan SDM pada Dinas Kepariwisataan Kabupaten Kepulauan Selayar. Lingkungan kerja berpengaruh positif terhadap pengembangan SDM pada Dinas Kepariwisataan Kabupaten Kepulauan Selayar.
\end{abstract}

Kata Kunci : Pelatihan dan Pendidikan, Lingkungan, Motivasi, Pariwisata, Selayar

\section{ABSTRACT}

This study aims to education and training have a positive effect on the development of human resources at the Selayar Islands District Tourism Office and work motivation have a positive effect on the development of HR in the Selayar Islands District Tourism Office. This type of research is descriptive quantitative, and the population and the sample in the study counted for 50 employees. Determination of the sample using the slavin theory and this study was analyzed through multiple linear regression analysis with the help of SPSS 23 software. The results showed that education and training had a positive and significant effect on HR development in the Selayar Islands District Tourism Office and work environment had a positive and significant effect on HR development in the Selayar Islands District Tourism Office.

Keywords: Education and Training, Environment, Motivation, Tourism, Selayar

\section{PENDAHULUAN}

Pengembangan sumber daya manusia menurut Priansa (2014), sebagai penyiapan individu karyawan untuk memikul tanggung jawab yang berbeda atau lebih tinggi di dalam organisasi. Wahjosumidjo (2004) berpendapat bahwa ada 3 (tiga) alasan utama yang mendorong perlunya motivasi dalam organisasi yaitu: (1) Untuk mengamati dan memahami tingkah laku bawahan: (2) Mencari dan menentukan sebab-sebab tingkah laku bawahan; dan (3) Memperhitungkan, mengawasi, dan mengubah serta mengarahkan tingkah laku bawahan. Sedangkan Kepemimpinan adalah keseluruhan aktivitas dalam rangka mempengaruhi seseorang agar mau bekerja untuk mencapai suatu tujuan yang diinginkan bersama. Kepemimpinan yang baik perlu dipelihara sebaikbaiknya, karena manajemen yang berhasil bersumber atau bergantung pada adanya kepemimpinan yang baik. (Susilo Martoyo, 2000).

Rachmawati (2008) menyatakan bahwa manajemen sumber daya manusia merupakan suatu proses perencanaan, pengorganisasian, pengarahan dan pengawasan kegiatan-kegiatan pengadaan, pengembangan, pemberian kompensasi, pengintegrasian, pemeliharaan dan pelepasan sumber daya manusia agar tercapai berbagai tujuan individu, organisasi dan masyarakat. Yuniarsih dan Suwatno (2008) mengemukakan bahwa, manajemen sumber daya manusia merupakan bagian dari ilmu manajemen yang memfokuskan perhatiannya pada pengaturan peranan sumber daya manusia dalam kegiatan suatu organisasi. Dessler (2008), manajemen sumber daya manusia adalah proses memperoleh, melatih, menilai, dan memberikan kompensasi kepada karyawan, memperhatikan hubungan kerja mereka, kesehatan, keamanan dan masalah keadilan. Hasibuan (2006), manajemen sumber daya manusia merupakan penyiapan dan pelaksanaan suatu rencana yang terkoordinasi untuk menjamin bahwa sumber daya manusia yang ada dapat dimanfaatkan dengan sebaik-baiknya untuk mencapai tujuan organisasi. Sofyandi (2008), manajemen sumber daya manusia merupakan suatu strategi dan menerapkan fungsi-fungsi manajemen yaitu planning, organizing, leading dan controlling, dalam setiap aktivitas/fungsi 
operasional sumber daya manusia. Sumber Daya Manusia mulai dari proses penarikan, seleksi, pelatihan dan pengembangan, penempatan yang meliputi promosi, demosi dan transfer, penilaian kinerja, pemberian kompensasi, hubungan industrial, hingga pemutusan hubungan kerja, yang ditujukan bagi peningkatan kontribusi produktif dari sumber daya manusia organisasi terhadap pencapaian tujuan organisasi secara lebih efektif dan efisien.

Pemerintah merupakan salah satu faktor penentu dalam proses pembangunan yang mantap dan dinamis sehingga dibutuhkan peranan yang lebih besar terutama dalam pelaksanaan pemerintahan. Kelancaran penyelenggaraan pemerintah dan pelaksanaan pembangunan memerlukan suatu pembinaan terhadap aparatur Negara. Oleh karena itu tidak dapat dipungkiri lagi bahwa faktor manusia merupakan modal utama yang perlu diperhatikan dalam suatu pemerintahan. Hal tersebut sangatlah penting karena bagaimanapun juga keberhasilan suatu organisasi dalam mencapai suatu tujuan di tentukan oleh kualitas dan kemampuan orangorang yang berada di dalamnya.

Sumber Daya Manusia merupakan aset atau unsur yang paling unik sekaligus penting diantara unsur- unsur organisasi lainnya. Hal yang membuat SDM disuatu organisasi unik karena manusia itu sendiri makhluk yang memiliki akal budi, punya kemampuan untuk berkembang, dan memiliki keinginan-keinginan berbeda dengan alat produksi lain yang tidak dapat berkembang kemampuannya serta tidak memiliki keinginan-keinginan. Oleh Karena itu tidak sama dengan alat produksi lain maka pengelolaan manusia pun bersifat unik.

Pengalaman menunjukkan bahwa dengan penyelenggaraan program pengenalan yang sangat komprehensif sekalipun belum menjamin bahwa para pegawai baru serta merta dapat melaksanakan tugas dengan memuaskan. Artinya para pegawai baru itu masih memerlukan pelatihan tentang berbagai segi tugas pekerjaan yang dipercayakan kepada mereka. Para pegawai yang sudah berpengalaman pun selalu memerlukan peningkatan pengetahuan, keterampilan dan kemampuan karena selalu ada cara yang lebih baik untuk meningkatkan produktivitas kerja. Belum lagi apabila seorang pegawai ditempatkan pada tugas pekerjaan yang baru. Tidak mustahil ada kebiasaan-kebiasaan kerja yang tidak atau kurang baik yang perlu dihilangkan. Singkatnya, kemampuan pegawai baru yang digabung dengan program pengenalan dan pelatihan tertentu belum sepenuhnya menjamin hilangnya kesenjangan antara kemampuan kerja dan tuntutan tugas. Disinilah letak pentingnya pengembangan SDM.

Ditinjau dari sudut pandang organisasi, manusia adalah sumber daya yang dinamis, bukan sumber daya yang statis seperti halnya tanah dan modal. Menurut Bintoro dan Daryanto (2017) menyatakan bahwa manajemen sumber daya manusia, disingkat MSDM, adalah suatu ilmu atau cara bagaimana mengatur hubungan dan peranan sumber daya (tenaga kerja) yang dimiliki oleh individu secara efisien dan efektif serta dapat digunakan secara maksimal sehingga tercapai tujuan bersama perusahaan,karyawan dan masyarakat menjadi maksimal. Kegiatan pengelolaan sumber daya manusia di dalam suatu organisasi dapat di klasifikasikan ke dalam beberapa fungsi, yaitu (1) Fungsi Perencanaan (Planning); (2) Fungsi Pengoorganisasian (Organizing): (3) Fungsi Pengarahan (Directing): dan (4) Fungsi Pengendalian (Controling).

Majunya teknologi dan berkembangnya informasi serta tersedianya modal dan bahan akan sulit bagi organisasi untuk mencapai tujuannya bila SDM tidak di perhatikan atau di telantarkan. Dalam rangka mencapai keberhasilan suatu organisasi atau, produktivitas kerja pegawai merupakan faktor penting yang harus di wujudkan untuk mendukung tercapainya tujuan organisasi. Aktivitas kerja senantiasa mempengaruhi produktivitas dalam organisasi sehingga dengan produktifnya pegawai dalam pelaksanaan tugas pokok, akan tercipta efektifitas dan efisiensi.

Untuk mewujudkan tujuan nasional dan pelaksanaan cita-cita bangsa dibutuhkan Pegawai ASN. Pegawai ASN diserahi tugas untuk melaksanakan tugas pelayanan publik, tugas pemerintahan, dan tugas pembangunan tertentu, maka perlu dibangun aparatur sipil negara yang memiliki integritas, profesional, netral dan bebas dari intervensi politik, bersih dari praktik korupsi, kolusi, dan nepotisme, serta mampu menyelenggarakan pelayanan publik bagi masyarakat dan mampu menjalankan peran sebagai unsur perekat persatuan dan kesatuan bangsa berdasarkan Pancasila dan Undang-Undang Dasar Negara Republik Indonesia Tahun 1945.

Penelitian ini bertujuan untuk mengetahui dan menganalisis pengaruh pendidikan dan latihan, terhadap pengembangan SDM pada Dinas Kepariwisataan Kabupaten Kepulauan Selayar, dan pengaruh motivasi kerja terhadap pengembangan SDM pada Dinas Kepariwisataan Kabupaten Kepulauan Selayar

\section{METODE PENELITIAN}

Penelitian di laksanakan di Kabupaten Kepulauan Selayar. Jenis penelitian ini adalah penelitian kuantitatif dengan menggunakan pendekatan analisis statistik deskriptif dan statistik infrensial (Sugiyono). Penelitian ini mengkaji tentang adanya hubungan assosiatif antara variabel bebas dan variabel independen. Responden sebanyak 50 orang.Teknik pengumpulan data digunakan dengan metode wawancara, observasi, dan kuesioner.

\section{HASIL DAN PEMBAHASAN}

Hasil penelitian menunjukkan analisi uji regresi berganda memiliki nilai konstanta sebesar 0,19 , nilai signifikansi untuk variabel pendidikan dan latihan adalah 0,007, variabel Lingkungan kerja memiliki nilai signifikansi sebesar 0,000. Variabel kepemimpinan memiliki nilai signifikansi sebesar 0,002 dan variabel motivasi kerja nilai signifikansinya sebesar 0,001 . Dari 
hasil perhitungan dapat dinyatakan bahwa masing-masing variabel bebas memperoleh nilai $\mathrm{t}$ - hitung $>\mathrm{t}$ - tabel, hal ini menjelaskan keempat variabel bebas memiliki pengaruh yang positif dan signifikan terhadap pengembangan SDM (sig $\leq 0,05)$. Berdasarkan hasil uji regresi berganda pada tabel tersebut maka diperoleh persamaan regresi berganda sebagai berikut :

$Y=0,190+0,256 X_{1}+0,432 X_{2}+0,333 X_{3}+0,347$

$\mathrm{X}_{4}$

Berdasarkan hasil persamaan regresi linear berganda tersebut dapat diuraikan bahwa :

1. Nilai konstanta sebesar 0,19 menyatakan bahwa jika variabel independen pendidikan dan latihan, motivasi kerja, kepemimpinan dan lingkungan kerja ada, maka pengembangan SDM akan meningkat sebesar 0,19 satuan.

2. Nilai koefisien pendidikan dan latihan sebesar 0,25 menyatakan bahwa variabel pendidikan dan latihan berpengaruh secara positif dan signifikan terhadap pengembangan SDM Dinas Kepariwisataan Kabupaten Kepulauan Selayar, atau dengan kata lain setiap terjadi kenaikan 1 skor pendidikan dan latihan akan diikuti oleh kenaikan pengembangan SDM sebesar 0,25 satuan.

3. Nilai koefisien Lingkungan kerja sebesar 0,43 menyatakan bahwa variabel lingkungan kerja berpengaruh secara positif dan signifikan terhadap pengembangan SDMDinas Kepariwisataan Kabupaten Kepulauan Selayar, atau dengan kata lain setiap terjadi kenaikan 1 skor lingkungan kerja akan diikuti oleh kenaikan pengembangan SDM sebesar 0,43 satuan.

4. Nilai koefisien kepemimpinan sebesar 0,33 menyatakan bahwa variabel kepemimpinan berpengaruh secara positif dan signifikan terhadap pengembangan SDMDinas Kepariwisataan Kabupaten Kepulauan Selayar, atau dengan kata lain setiap terjadi kenaikan 1 skor kepemimpinan akan diikuti oleh kenaikan pengembangan SDM sebesar 0,43 satuan.

5. Nilai koefisien Motivasi kerja sebesar 0,34 menyatakan bahwa variabel motivasi kerja berpengaruh secara positif dan signifikan terhadap pengembangan SDM Dinas Kepariwisataan Kabupaten Kepulauan Selayar, atau dengan kata lain setiap terjadi kenaikan 1 skor motivasi kerja akan diikuti oleh pengembangan SDM sebesar 0,34 satuan.
Berdasarkan persamaan regresi linear berganda terhadap keempat variabel independen pendidikan dan latihan, motivasi kerja, lingkungan kerja dan kepemimpinan terhadap pengembangan SDM, terlihat bahwa variabel Lingkungan kerja $\left(\mathrm{X}_{2}\right)$ memiliki angka unstandardized coefisient atau angka beta paling besar yaitu 0,432 , dibandingkan motivasi kerja $\left(\mathrm{X}_{3}\right)$ sebesar 0,34 dan variabel pendidikan dan latihan $\left(\mathrm{X}_{1}\right)$ sebesar 0,25 serta kepemimpinan sebesar 0,33. Hal ini menunjukkan bahwa variabel Lingkungan kerja merupakan variabel yang berpengaruh paling tinggi terhadap pelaksanaan pengembangan SDM pada Dinas Kepariwisataan Kabupaten Kepulauan Selayar.Uraian tersebut menunjukkan bahwa variabel Lingkungan kerja $\left(\mathrm{X}_{2}\right)$ mempunyai peranan yang lebih penting dalam meningkatkan pengembangan SDM pada Dinas Kepariwisataan Kabupaten Kepulauan Selayar.

\section{KESIMPULAN}

Kesimpulan dari penelitian adalah pendidikan dan latihan berpengaruh positif dan signifikan pengembangan SDM pada Dinas Kepariwisataan Kabupaten Kepulauan Selayar dan motivasi kerja berpengaruh positif dan signifikan terhadap pengembangan SDM pada Dinas Kepariwisataan Kabupaten Kepulauan Selayar

\section{DAFTAR PUSTAKA}

Bintoro dan Daryanto. 2017. Manajemen Penilaian Kinerja Karyawan. Cetakan 1. Yogyakarta : Gava Media.

Dessler Gary, 2008. Manajemen Sumber Daya Manusia, Edisi Kesepuluh Jilid I, Indeks Jakarta.

Donni Junni Priansa 2014, Perencanaan \& Pengembangan SDM, Penerbit Bandung: Alfabeta.

Hasibuan Malayu S.P, 2006. Manajemen Sumber Daya Manusia. Edisi Revisi, Cetakan Kedelapan PT. Bumi Aksara, Jakarta.

Rachmawati Ike Kusdyah, 2008. Manajemen Sumber Daya Manusia, Edisi Pertama, Cetakan Pertama, Penerbit: Andi Offset, Jakarta

Susilo, Martoyo, 1999, Sumber Daya Manusia, BPFE, Yogyakarta.

Sugiyono, 2010. Metode Penelitian Kuantitatif, Kualitatif, dan R dan D. Jakarta: Alfabeta.

Sofyandi Herman, 2008. Manajemen Sumber Daya Manusia, Edisi Pertama, Cetakan Pertama, Penerbit : Graha Ilmu, Jakarta.

Undang-undang No.5 Tahun 2014 tentang ASN

Wahjosumidjo. (2004). Kepemimpinan Kepala Sekolah tinjauan Teoritik dan Permasalahannya. Jakarta : PT. Raja Grafindo

Yuniarsih Tjutju, dan Suwatno, 2008. Manajemen Sumber Daya Manusia, Cetakan Pertama, Penerbit : Alfabeta, Bandung 